\title{
Fine-scale vertical position as an indicator of vegetation in alkali grasslands - Case study based on remotely sensed data
}

\author{
Balázs Deák ${ }^{\mathrm{a}, \mathrm{b}}$, Orsolya Valkó ${ }^{\mathrm{a}, *}$, Cici Alexander ${ }^{\mathrm{b}}$, Werner Mücke ${ }^{\mathrm{c}}$, Adam Kania ${ }^{\mathrm{b}, \mathrm{d}}$, \\ János Tamás ${ }^{\mathrm{e}}$, Hermann Heilmeier ${ }^{\mathrm{b}}$ \\ a MTA-DE Biodiversity and Ecosystem Services Research Group, Egyetem tér 1, Debrecen H-4032, Hungary \\ b Technische Universität Bergakademie Freiberg, Interdisciplinary Ecological Centre, Leipziger Str. 29, Freiberg D-09596, Germany \\ c Vienna University of Technology, Department of Geodesy and Geoinformation, Gußhausstraße 27-29, Vienna A-1040, Austria \\ d ATMOTERM S.A., ul. Łangowskiego 4, 45-031 Opole, Poland \\ e University of Debrecen, Böszörményi út 138, Debrecen H-4032, Hungary
}

\section{A R T I C L E I N F O}

\section{Article history:}

Received 19 May 2014

Received in revised form 9 September 2014

Accepted 12 September 2014

Edited by Brigitta Erschbamer

Available online $\mathrm{xxx}$

\section{Keywords:}

Vegetation zonation

Airborne laser scanning

Saline grassland

Festucion pseudovinae

Natura 2000

Digital terrain model

\begin{abstract}
A B S T R A C T
Vertical position is an important driver of vegetation zonation at multiple scales, via determining abiotic environmental parameters, such as climate, soil properties and water balance. In inland alkali landscapes, elevation is a key factor for understanding patterns of salt accumulation and water table which is therefore considered a good indicator of alkali vegetation types. Remote sensing techniques offer viable solutions for linking elevation data to vegetation patterns by providing an elevation model of extended areas. Our goal was to test the relationships between fine-scale differences in vertical position and vegetation patterns in inland alkali landscapes by vegetation data collected in the field and elevation data generated using airborne laser scanning (ALS). We studied whether vertical position influences vegetation patterns at the level of main vegetation groups (based on alliances) or even at the level of associations. Our study sites were situated in a lowland alkali landscape in Hortobágy National Park (East-Hungary). We grouped the associations into four main vegetation groups: loess grasslands, alkali steppes, open alkali swards and alkali meadows. Even though we detected a very limited range $(121 \mathrm{~cm})$ in the vertical position of the main vegetation groups, they were well separated by their vertical positions. At the level of associations, a more detailed elevation-based distinction was also possible in many cases. The revealed elevation-vegetation correlations show that high-resolution mapping based on ALS remote sensing techniques is an ideal solution in complex lowland areas, such as alkali landscapes. Our findings suggest that in other types of lowland landscapes, characterised by elevation differences, the applied method might hold a great potential as a supporting tool for vegetation mapping.
\end{abstract}

(c) 2014 Elsevier GmbH. All rights reserved.

\section{Introduction}

Linking vegetation patterns to abiotic environmental parameters has been a core topic in vegetation ecology for centuries (Watt, 1947). Elevation above sea level is an important driver of vegetation zonation at multiple scales (Lundholm, 2009). In case of large elevation gradients, the relationship between vegetation zonation and elevation is well-described, e.g. in mountain areas (Krömer et al., 2013; Ostendorf et al., 1999). In these areas elevation is a

Abbreviations: ALS, airborne laser scanning; DTM, digital terrain model; RS, remote sensing.

* Corresponding author. Tel.: +36 305190316.

E-mail addresses: debalazs@gmail.com (B. Deák), valkoorsi@gmail.com (O. Valkó) primary determinant of meso-climate, thus it is a good predictor of the potential vegetation type. In lowland regions elevation gradients occur typically on smaller scales, mainly connected to small-scale differences in water table, salinity, soil texture or nutrient availability (see e.g. Wesche et al., 2005). For instance, several lowland landscapes, such as inland sand dunes, karst or alluvial areas are characterised by heterogeneous structure, where smallscale differences in elevation can affect vegetation patterns (see Bátori et al., 2009; Moeslund et al., 2013a; Török et al., 2009). Saltaffected habitat complexes in lowland areas are ideal systems for studying elevation-vegetation correlations. These areas are characterised by a high level of small-scale elevation heterogeneity, which corresponds to different levels of abiotic stress, i.e. salt content and water availability (Wanner et al., 2014). In former studies elevation differences within the tidal range were found to be a major predictor of vegetation zonation in coastal salt-affected associations 
(Minden et al., 2012; Zedler et al., 1999). In inland salt-affected landscapes the relationship between elevation and vegetation has been rarely studied.

Inland alkali grasslands are typical in continental climate, at sites with at least moderate salt concentration in the soil and dynamic changes in water regime (Deák et al., 2014; Eliáš et al., 2013; Valkó et al., 2014). Alkali landscapes of the Pannonian biogeographical region represent the most continuous salt-affected landscape in continental Europe with an extension of more than 210,000 ha (Šefferova Stanova et al., 2008). These landscapes hold an extremely high habitat diversity with numerous associations which form a very complex and heterogeneous mosaic structure even at a very fine-scale (Dítě et al., 2010a; Eliáš et al., 2013; Török et al., 2012) (Appendix A).

Species pool and spatial patterns of various grassland associations are driven by two main stress factors: salt- and water stress (Eliáš et al., 2013; Török et al., 2012; Zalatnai and Körmöczi, 2004). Therefore the amount and distribution of alkali salts in the soil together with the groundwater level determine vegetation patterns through environmental filtering (Molnár and Borhidi, 2003; Szombathová et al., 2008; Valkó et al., 2014). Based on this relationship Tóth and Kertész (1996) suggested using vegetation types for predicting soil parameters, such as $\mathrm{pH}$, electrical conductivity and sodium activity. In areas located within a few metres of vertical distance from a water table, fine-scale elevation differences markedly affect local patterns in soil moisture (Moeslund et al., 2013a,b). Thus, elevation is a key factor for understanding salt accumulation patterns and water table level in inland alkali landscapes; for instance Zalatnai et al. (2007) suggested that the position along an elevation gradient was the most important factor affecting soil properties. Other studies proved that groundwater level and salinity significantly correlate with small-scale elevation differences in ground surface (Blaskó et al., 2006; Valkó et al., 2014). Based on vegetation-soil and soil-elevation relationships, it has been widely accepted that vegetation patterns show a distinct correlation with elevation in inland alkali landscapes, which was in line with numerous field observations (Molnár and Borhidi, 2003; Török et al., 2012; Appendix B). Similar small-scale elevation-vegetation correlations were confirmed by measurements in seashore landscapes (Moeslund et al., 2011; Ward et al., 2013). However, in inland alkali landscapes, systematic field measurements confirming the correlation between elevation and vegetation types along entire zonation gradients are still lacking.

Airborne laser scanning (ALS) became a widely available and therefore increasingly used tool in ecological studies, as it can provide reliable data on structural attributes of extended areas (Lefsky et al., 2002). ALS is an active remote sensing technique which can be used without the utilisation of sunlight and therefore it is highly insensitive to weather conditions. This emits short pulses of (usually infrared) light from airborne platforms, typically fixed-wing aircrafts or helicopters. The distances to target surfaces can subsequently be computed by measuring the time the pulse takes to travel from scanner to target and back (Wehr and Lohr, 1999). ALS has proven to be a useful tool for collecting information from the ground surface and generating digital terrain models (DTM) in open ecosystems with low amounts of biomass and vegetation cover. Therefore, for linking elevation data with vegetation patterns ALS offers a viable solution (Ward et al., 2013).

Our goal was to test the correlation between fine-scale differences in vertical position and vegetation patterns in inland alkali landscapes by vegetation data collected in the field and elevation data generated from airborne laser scanned data. We studied whether the vertical position influences vegetation patterns at the level of main vegetation groups or even at the level of associations.

\section{Materials and methods}

\section{Study site}

Our study site is situated in Ágota Puszta (N $47^{\circ} 21^{\prime}$ E $21^{\circ} 04^{\prime}$ ), a lowland alkali landscape, which is part of the Hortobágy National Park (East-Hungary). Ágota Puszta is characterised by a complex mosaic of alkali and loess vegetation. Smaller patches of non-alkali wetlands (marshes with Typha spp. and Glyceria maxima) and scattered woody vegetation (oak plantations and smaller patches of invasive woody species, such as Eleagnus angustifolia and Fraxinus pennsylvanica) are present as well, mainly connected to old riverbeds. Grasslands of the study area are managed uniformly by moderate (1.2 livestock unit/hectare/year) cattle grazing herded by herdsmen. The area is characterised by a continental climate with a mean annual temperature of $9.5^{\circ} \mathrm{C}$ and mean annual precipitation of $550 \mathrm{~mm}$ (Török et al., 2012). The total elevation range within the study site $(1 \mathrm{~km} \times 2 \mathrm{~km})$ is as low as $1.8 \mathrm{~m}$ (128.7-126.9 $\mathrm{m}$ a.s.l.) from the lowest elevations to the top of the plateaux.

\section{Studied associations and main vegetation groups}

We studied eight grassland associations, typical to alkali and chernozem soils, which are present in our study sites. Typical species and environmental characteristics of the studied associations are listed in Table 1. We justified the assignment of polygons to association types based on the constancy of the dominant species defined by a cover $>5 \%$ (Appendix C, see also Borhidi et al., 2012). For further analyses we grouped the associations into four main vegetation groups The grouping refers to larger phytosociological units (Borhidi et al., 2012), i.e. alliances as follows: (i) Loess grasslands: alliance Festucion valesiacae; (ii) Alkali steppes: alliance Festucion pseudovinae; (iii) Open alkali swards: alliances Puccinellion limosae and Salicornion prostratae; (iv) Alkali meadows: alliance Beckmannion eruciformis.

\section{Loess grasslands}

This group comprises only one association: Cynodonti-Poetum angustifoliae (hereafter mentioned as Cynodonti-Poetum). Loess grasslands are short grasslands on chernozem soils, characterised by a high diversity of monocot and forb species (Borhidi et al., 2012). Due to the high fertility of their soil, weedy species are often typical in loess grasslands.

\section{Alkali steppes}

Alkali steppes are short, dry grasslands formed on solonetz soils with moderate humus content and low to moderate salt accumulation in the deeper soil layers (Török et al., 2012). In our study site two associations were present: Achilleo seataceae-Festucetum pseudovinae (hereafter Achilleo-Festucetum) and Artemisio santonici-Festucetum pseudovinae (hereafter Artemisio-Festucetum). The species pool of Achilleo-Festucetum steppes shows similarity to loess grasslands; Artemisio-Festucetum steppes show a definite alkali character indicated by several salt-tolerant species.

\section{Open alkali swards}

The most strongly salt-affected associations can be found in this group. Open alkali swards are generally covered by water in springtime, and salt accumulates in the upper soil layer or even on the soil surface. Due to the high salt content of the soil open alkali swards have a low vegetation cover (5-30\%) and a species-poor vegetation mainly built by halophyte species (Török et al., 2012). They comprise three associations: Camphorosmetum annuae; Puccinellietum 
Table 1

Environmental characteristics of the studied associations (after Kelemen et al., 2013; Deák et al., 2014).

\begin{tabular}{|c|c|c|c|c|}
\hline Main vegetation groups & Association & Number of polygons & Soil salt content & Water balance \\
\hline Loess grasslands & Cynodonti-Poetum angustifoliae & 23 & Low & Dry/stable \\
\hline Alkali steppes & $\begin{array}{l}\text { Artemisio santonici-Festucetum pseudovinae } \\
\text { Achilleo seataceae-Festucetum pseudovinae }\end{array}$ & $\begin{array}{l}13 \\
61\end{array}$ & $\begin{array}{l}\text { Moderate } \\
\text { Low }\end{array}$ & $\begin{array}{l}\text { Dry/astatic } \\
\text { Dry/stable }\end{array}$ \\
\hline Open alkali swards & $\begin{array}{l}\text { Camphorosmetum annuae } \\
\text { Puccinellietum limosae } \\
\text { Pholiuro pannonici-Plantaginetum tenuiflorae }\end{array}$ & $\begin{array}{l}14 \\
23 \\
18\end{array}$ & $\begin{array}{l}\text { High } \\
\text { High } \\
\text { High }\end{array}$ & $\begin{array}{l}\text { Dry/astatic } \\
\text { Dry/astatic }^{\mathrm{a}} \\
\text { Dry/astatic }^{\mathrm{a}}\end{array}$ \\
\hline Alkali meadows & $\begin{array}{l}\text { Agrostio stoloniferae-Alopecuretum pratensis } \\
\text { Agrostio stoloniferae-Beckmannietum eruciformis }\end{array}$ & $\begin{array}{l}27 \\
14\end{array}$ & $\begin{array}{l}\text { Low } \\
\text { Low-moderate }\end{array}$ & $\begin{array}{l}\text { Mesic/astatic } \\
\text { Mesic }^{\mathrm{b}}\end{array}$ \\
\hline
\end{tabular}

a Rapid seasonal changes in water balance; usually wet in early spring, then getting dried before summer.

b Covered by water in spring, drying out till summer.

limosae; Pholiuro pannonici-Plantaginetum tenuiflorae (hereafter Camphorosmetum, Puccinellietum and Pholiuro-Plantaginetum).

\section{Alkali meadows}

Alkali meadows are wet grasslands characterised by tall grass species. Generally they dry out in mid-summer and have a low to moderate salt content in the soil (Deák et al., 2014). They comprise two associations in the study site: Agrostio stoloniferae-Alopecuretum pratensis (hereafter Agrostio-Alopecuretum) and Agrostio stoloniferae-Beckmannietum eruciformis (hereafter Agrostio-Beckmannietum). Compared to Agrostio-Alopecuretum, Agrostio-Beckmannietum typically grows on more wet and alkali soils, which is indicated by several halophyte species and species of salt marshes, like Cirsium brachycephalum.

\section{ALS data collection and pre-processing}

The ALS data were acquired using a RIEGL LMS-Q680i fullwaveform laser scanner mounted on a fixed wing aircraft in March 2012 in the framework of the ChangeHabitats2 EU FP7 project. The average point density was estimated as $25 \mathrm{pts} / \mathrm{m}^{2}$, considering all types of echoes (first, intermediate, last). A fine-scale DTM was derived from the ALS point cloud with a grid size of $0.25 \mathrm{~m} \times 0.25 \mathrm{~m}$ using the software SCOP++ (2008). Vertical accuracy of an ALS echo was determined to be less than $0.05 \mathrm{~m}$.

\section{Field data collection}

Field data were collected in June 2013. Based on the DTM, we designated fifteen transects ( $150 \mathrm{~m}$ long, $30 \mathrm{~m}$ wide) along an elevation gradient from the highest elevated plateaux to the lowest-elevated areas. We mapped all typical associations (in total 193 polygons) in transects and measured their positions with a Trimble Geoexplorer 6000 differential GPS. We recorded the dominant species in each polygon and then assigned the polygons into association types (see Table 1) using the categories suggested by Borhidi et al. (2012). Data from the polygons recorded in the field were processed in ArcGIS 10.1; the areas of the polygons were standardised to the area of the smallest patch $\left(4 \mathrm{~m}^{2}\right)$ which yielded 64 DTM grids with discrete elevation data.

\section{Data analysis}

We compared the vertical positions of the main vegetation groups and the associations with a Kruskal-Wallis test (Zar, 1999). Then we calculated the pairwise comparisons with Mann-Whitney (M-W) test (Bonferroni adjusted) using SPSS 20.0. For the calculations we used averaged elevation data from each polygon.

\section{Results}

\section{Main vegetation groups}

Even though we detected a very limited range in the vertical position $(121 \mathrm{~cm})$ of the main vegetation groups, they were well separated along vertical positions $(N=193$; $\mathrm{df}=3 ; p<0.001)$ (Fig. 1A). Loess grasslands were characterised by the highest vertical position. Alkali steppes were situated below loess grasslands; they were well separated from each other by vertical position $(p<0.001)$. Open alkali grasslands had an intermediate position between the alkali steppes and alkali meadows. Alkali meadows were situated in the lowest elevations, clearly separated from open alkali swards $(p<0.001)$.

\section{Association types}

Although we found significant differences between the vertical positions of the studied associations $(N=193 ; \mathrm{df}=7 ; p<0.001)$ (Fig. 1B), the pairwise comparisons showed that not all association types were clearly separated by vertical positions. Based on their vertical position, the order of association types is as follows.

Stands of Cynodonti-Poetum were located at the highest positions; they formed a quite well-separated group, overlapping only with Artemisio-Festucetum stands.

Artemisio-Festucetum stands overlapped with stands of Cynodonti-Poetum above, and Achilleo-Festucetum and Camphorosmetum below. Achilleo-Festucetum stands had a rather wide elevation range $(110 \mathrm{~cm})$ in their vertical position, thus they covered almost the whole gradient. This type overlapped with Artemisio-Festucetum stands above and also with the stands of all of the open alkali grassland associations below. Achilleo-Festucetum was significantly separated from the Cynodonti-Poetum $(p<0.001)$ and from both alkali meadow associations ( $p<0.001$ for each).

Camphorosmetum stands overlapped with both the stands of alkali steppe associations above and with all other open alkali grassland associations below. Camphorosmetum stands differed significantly from the Cynodonti-Poetum stands $(p=0.015)$ and stands of both alkali meadow associations $(p=0.001$ for each). Puccinellietum stands differed significantly from stands of Cynodonti-Poetum $(p=0.001)$ and Artemisio-Festucetum above $(p=0.017)$, and both alkali meadow associations below (Agrostio-Alopecuretum $\quad p=0.021 ;$ Agrostio-Beckmannietum $p=0.018$ ). Pholiuro-Plantaginetum stands overlapped with almost all of the studied associations, except for Cynodonti-Poetum $(p<0.001)$ and Artemisio-Festucetum $(p=0.001)$ stands.

Stands of Agrostio-Alopecuretum were well separated from all other associations except for the Pholiuro-Plantaginetum and Agrostio-Beckmannietum stands. Stands of Agrostio-Beckmannietum were situated at the lowest position. They were well separated from all other associations 

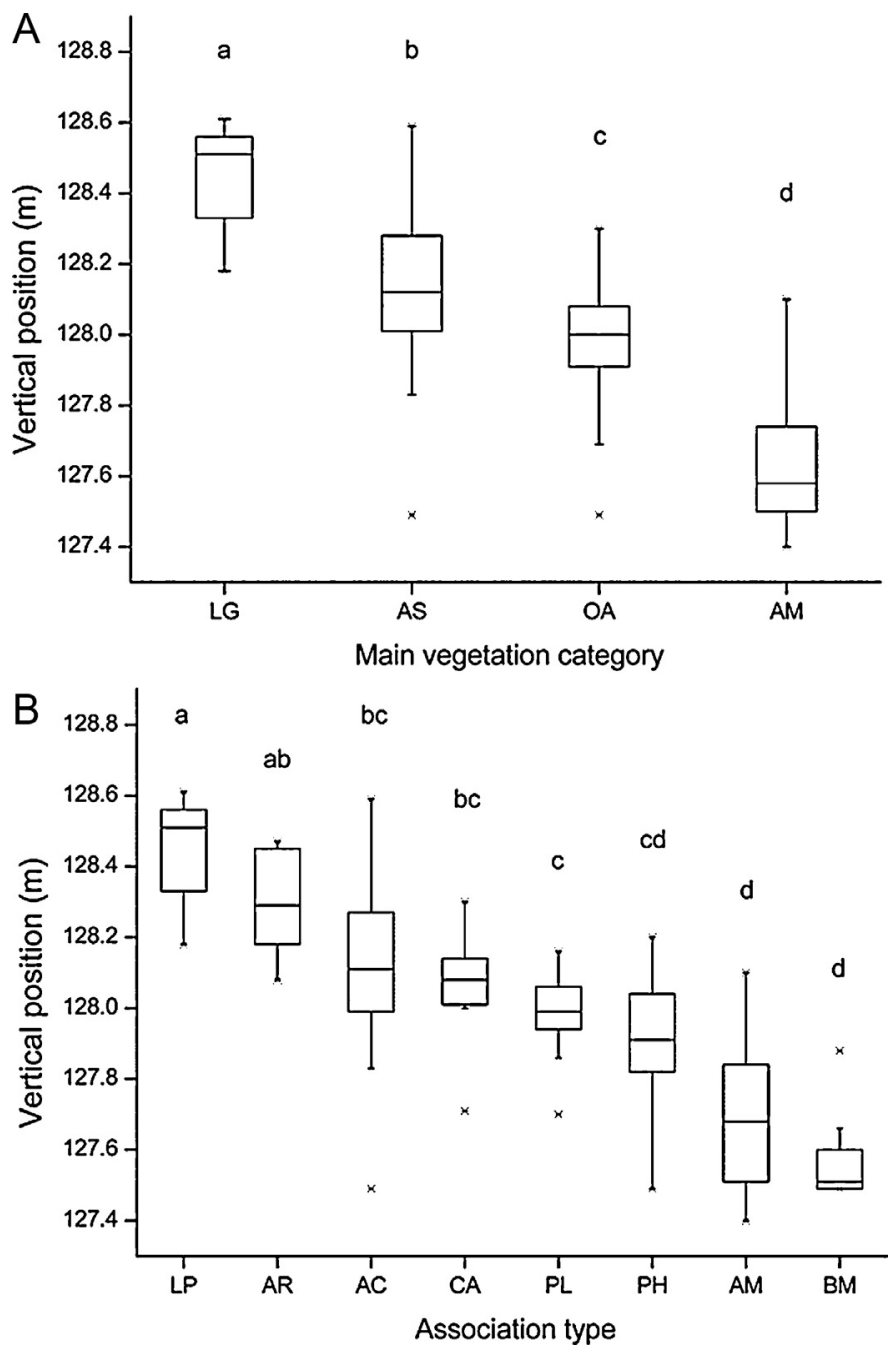

Fig. 1. (A) Elevation of main vegetation groups. (B) Elevation of the studied association types. Boxes indicate the $25-75$ percentiles, lines are the medians, and the asterisks are the outliers. Significant differences between the different groups are indicated by different letters (Mann-Whitney test, $p<0.05$ ). Abbreviations of the main vegetation groups: LG - loess grassland; AS - alkali steppes; OA - open alkali grassland; AM - alkali meadows; Abbreviations of the associations: $\mathrm{CP}$ Cynodonti-Poetum; AF - Achilleo-Festucetum; AR - Artemisio-Festucetum; CA - Camphorosmetum annuae; PP - Pholiuro-Plantaginetum; PL - Puccinellietum limosae; AA - Agrostio-Alopecuretum; AB - Agrostio-Beckmannietum.

except for the Pholiuro-Plantaginetum and Agrostio-Alopecuretum stands.

\section{Discussion}

We found that the main vegetation groups (loess grasslands, alkali steppes, open alkali swards and alkali meadows) of alkali landscapes can be clearly separated by fine-scale differences in their vertical position. This clear distinction is probably caused by the differences in the environmental conditions of the main vegetation groups (Borhidi et al., 2012). Loess grasslands are exposed to drought stress, but not affected by salt-stress and nutrientdeficiency. In contrast alkali steppes are exposed to moderate levels of drought and salt-stress; open alkali swards are exposed to high levels of drought and salinity; while alkali meadows are characterised by no drought and only moderate salt stress (Deák et al., 2014; Kelemen et al., 2013). Thus, these marked differences in abiotic stress factors - especially topographically controlled soil moisture and salinity (Moeslund et al., 2013a,b) - likely resulted in the clear separation of main vegetation groups.

At the level of association types, a more detailed elevation-based distinction was also possible in many cases. Based on the DTM we revealed a fine-scale vertical vegetation gradient.

We found that Cynodonti-Poetum was situated on the top part of the gradient. They were typically situated on the highly elevated plateaux, which probably provided optimal conditions (nutrientrich chernozem soil, low salt content and dry conditions) for loess grassland species, such as Euphorbia cyparissias, Festuca rupicola and Galium verum (Kelemen et al., 2013).

Below Cynodonti-Poetum, Artemisio-Festucetum was situated, overlapping with the Cynodonti-Poetum, Achilleo-Festucetum and even with open alkali swards in its vertical extent. Achilleo-Festucetum had the widest range of vertical position in our study site, likely because this association is characterised by moderate soil fertility and/or moderate salinity, which conditions are likely provided in different elevation zones (Kelemen et al., 2013). Accordingly its species pool includes some generalist species, shared with neighbouring associations, such as Achillea spp. and Plantago lanceolata with Cynodonti-Poetum, Achillea spp., Festuca pseudovina and Podospermum canum with Artemisio-Festucetum. Presence of generalist species and wide distribution of this association can be linked to the hypothesis of Molnár and Borhidi (2003) on the secondary origin of this association. They assume that several stands of Achilleo-Festucetum have originated from other associations typical to alkali landscapes (Molnár and Borhidi, 2003); which resulted in a species pool comprising generalist species.

Associations of the open alkali swards, such as Camphorosmetum, Puccinellietum and Pholiuro-Plantaginetum had a very similar vertical position in an intermediate position between alkali steppes and alkali meadows. These three associations are characterised by high salt-content on the soil surface, high groundwater table but dry soil surface after springtime (Dítě et al., 2010b; Valkó et al., 2014). These special environmental conditions are restricted to a narrow elevation zone, which was confirmed by the vertical position of Camphorosmetum and Puccinellietum. Pholiuro-Plantaginetum showed similarity to alkali meadows in their vertical position, even it was not indicated by the dominant species, which is probably due to intense silt accumulation processes typical both in Pholiuro-Plantaginetum and alkali meadows (Borhidi et al., 2012; Deák et al., 2014).

Alkali meadows were present in the lowest positions and were clearly separated from all other associations, except for the Pholiuro-Plantaginetum. Agrostio-Alopecuretum which had a wider range in vertical position compared to Agrostio-Beckmannietum. Agrostio-Beckmannietum is typical on mesic habitats with moderate or intense salt accumulation (Deák et al., 2014), indicated by the presence of Beckmannia eruciformis and Glyceria fluitans; these conditions are probably restricted to a limited elevation zone. In contrast, Agrostio-Alopecuretum stands are typical in astatic habitats with only moderate level of salt accumulation (Deák et al., 2014) which conditions are likely provided in a wider range of vertical position.

Our results clearly demonstrated that the main vegetation groups and associations of alkali landscapes are positioned along a vertical elevation gradient of even a couple of decimetres. These differences likely correspond to environmental gradients (soil type, salt accumulation and water balance) which are strongly correlated to elevation patterns (Tóth and Kertész, 1996; Tóth, 2010). At the association level the vertical elevation gradient could be detected, but vertical position of certain associations overlapped. Overlaps were typically found between associations characterised by similar environmental conditions.

We proved that the distribution of alkali vegetation types can be extracted from remotely sensed elevation data. We found that 
in these landscapes, even within a range of only $1 \mathrm{~m}$, main vegetation groups and association types can be separated based on their vertical position. Our findings also support the idea that in other types of lowland landscapes (see e.g. Moeslund et al., 2011; Ward et al., 2013), characterised by even larger elevation differences, the applied method might hold a great potential as a supporting tool for vegetation mapping. Elevation-vegetation correlations provide a good basis for practical application of ALS data in vegetation mapping of complex lowland landscapes, such as inland alkali habitats, large alluvial plains or vegetation mosaics of fens and dry grasslands. High resolution vegetation mapping in such heterogeneous landscapes is a challenging task for nature conservation managers given the complexity and fine-scale mosaic structure of the vegetation. Our results suggest that the application of DTM can considerably increase the accuracy and efficiency of vegetation mapping campaigns in landscapes with a heterogeneous configuration of habitats.

\section{Acknowledgements}

The study was funded by the ChangeHabitats2 project (Marie Curie - FP7 PEOPLE-2009-IAPP - Grant Agreement Number 251234). The authors express their gratitude to RIEGL Laser Measurements $\mathrm{GmbH}$ for providing the ALS data for the study for free. We are indebted to Z. Végvári, who kindly improved our English. O.V. was supported by the European Union and the State of Hungary, co-financed by the European Social Fund in the framework of TÁMOP-4.2.4.-A/2-11-1-2012-0001 'National Excellence Program'. B.D. was supported by the Internal Research Grant of the University of Debrecen and OTKA PD 111807. We are grateful to colleagues of Hortobágy National Park Directorate (I. Kapocsi, K. Hoffmann, L. Gál) for their support.

\section{Appendix A. Supplementary data}

Supplementary data associated with this article can be found, in the online version, at http://dx.doi.org/10.1016/j.flora.2014.09.005.

\section{References}

Bátori, Z., Csiky, J., Erdős, L., Morschhauser, T., Török, P., Körmöczi, L., 2009. Vegetation of the dolines in Mecsek mountains (South Hungary) in relation to the local plant communities. Acta Carsol. 38, 237-252.

Blaskó, L., Tamás, J., Czimbalmos, R., 2006. Substance regime processes depending on microrelief in a salt affected natural grassland. Cereal Res. Commun. 34, 143-146.

Borhidi, A., Kevey, B., Lendvai, G., 2012. Plant Communities of Hungary. Budapest, Akadémiai Kiadó.

Deák, B., Valkó, O., Török, P., Tóthmérész, B., 2014. Solonetz meadow vegetation (Beckmannion eruciformis) in East-Hungary - an alliance driven by moisture and salinity. Tuexenia 34, 187-203.

Dítě, D., Eliáš, P., Šuvada, R., Šová, A.P., Melečková, Z., 2010a. Current distribution and stage of community Artemisio santonici-Festucetum pseudovinae in Slovakia. Thaiszia 20, 77-86

Dítě, D., Eliáš, P., Šuvada, R., Szombathová, N., 2010b. The ecology and the coenotic characteristics of the Pholiuro pannonici-Plantaginetum tenuiflorae in the Pannonian Basin. Phyton 49, 293-312.

Eliáš, P., Sopotlieva, D., Dítě, D., Hájková, P., Apostolova, I., Senko, D., Melečková, Z., Hájek, M., 2013. Vegetation diversity of salt-rich grasslands in Southeast Europe. Appl. Veg. Sci. 16, 521-537
Kelemen, A., Török, P., Valkó, O., Miglécz, T., Tóthmérész, B., 2013. Mechanisms shaping plant biomass and species richness: plant strategies and litter effect in alkali and loess grasslands. J. Veg. Sci. 24, 1023-1195.

Krömer, T., Acebey, A., Kluge, J., Kessler, M., 2013. Effects of altitude and climate in determining elevational plant species richness patterns: a case study from Los Tuxtlas, Mexico. Flora 208, 197-210.

Lefsky, M.A., Cohen, W.B., Parker, G.G., Harding, D.J., 2002. Lidar remote sensing for ecosystem studies. Bioscience 52, 19-30.

Lundholm, J.T., 2009. Plant species diversity and environmental heterogeneity: spatial scale and competing hypotheses. J. Veg. Sci. 20, 377-391.

Minden, V., Andratschke, S., Spalke, J., Timmermann, H., Kleyer, M., 2012. Plant trait-environment relationships in salt marshes: deviations from predictions by ecological concepts. Persp. Plant Ecol. Evol. Syst. 14, 183-192.

Moeslund, J.E., Arge, L., Bøcher, P.L., Nygaard, B., Svenning, J.C., 2011. Geographically comprehensive assessment of salt-meadow vegetation-elevation relations using LiDAR. Wetlands 31, 471-482.

Moeslund, J.E.M., Arge, L., Bøcher, P.K., Dalgaard, T., Svenning, J.-C., 2013a. Topography as a driver of local terrestrial vascular plant diversity patterns. Nordic J. Bot. 31, 129-144.

Moeslund, J.E.M., Arge, L., Bøcher, P.K., Dalgaard, T., Erjnaes, R., Odgaard, M.V., Svenning, J.-C., 2013b. Topographically controlled soil moisture drives plant diversity patterns within grasslands. Biodiv. Conserv. 22, 2151-2166.

Molnár, Z.S., Borhidi, A., 2003. Hungarian alkali vegetation: origins, landscape history, syntaxonomy, conservation. Phytocoenologia 33, 377-408.

Ostendorf, B., Hilbert, D.W., Köstner, B., Tappeiner, U., Tasser, E., 1999. Toward a predictive understanding of ecosystem processes at the scale of landscapes. In: Oxley, L., Scrimgeour, F., McAleer, M. (Eds.), International Congress on Modelling and Simulation Proceedings, vol. 3. The Modelling and Simulation Society of Australian and New Zealand, Canberra. , pp. 685-690.

SCOP++, 2008. Department of Geodesy and Geoinformation, Research Groups Photogrammetry and Remote Sensing, Vienna, Austria. http://photo.geo. tuwien.ac.at/software/scop/

Šefferova Stanova, V., Janak, M., Ripka, J., 2008. Management of Natura 2000 Habitats. 1530 *Pannonic Salt Steppes and Salt Marshes. European Commission.

Szombathová, N., Eliáš, P., Dítě, D., Macák, M., 2008. Soil properties and vegetation on saline-sodic soil in the Nature Reserve Mostová. Folia Oecol. 35, 60-66.

Török, P., Kapocsi, I., Deák, B., 2012. Conservation and management of alkali grassland biodiversity in Central-Europe. In: Zhang, W.J. (Ed.), Grasslands: Types, Biodiversity and Impacts. Nova Science Publishers Inc., New York, pp. 109118 .

Török, P., Matus, G., Papp, M., Tóthmérész, B., 2009. Seed bank and vegetation development of sandy grasslands after goose breeding. Folia Geobot. 44, 3146.

Tóth, T., 2010. Medium-term vegetation dynamics and their association with edaphic conditions in two Hungarian saline grassland communities. Grassland Sci. 56, 13-18.

Tóth, T., Kertész, M., 1996. Application of soil-vegetation correlation to optimal resolution mapping of solonetzic rangeland. Arid Soil Res. Rehabil. 10, 1-12.

Valkó, O., Tóthmérész, B., Kelemen, A., Simon, E., Miglécz, T., Lukács, B., Török, P., 2014. Environmental factors driving vegetation and seed bank diversity in alkali grasslands. Agric. Ecosyst. Environ. 182, 80-87.

Wanner, A., Suchrow, S., Kiehl, K., Meyer, W., Pohlman, N., Stock, M., Jensen, K., 2014. Scale matters: impact of management regime on plant species richness and vegetation type diversity in Wadden Sea salt marshes. Agric. Ecosyst. Environ. 182, 69-79.

Ward, R.D., Burnside, N.G., Joyce, C.B., Sepp, K., 2013. The use of medium point density LiDAR elevation data to determine plant community types in Baltic coastal wetlands. Ecol. Indic. 33, 96-104.

Watt, A.S., 1947. Pattern and process in the plant community. J. Ecol. 35, 1-22.

Wehr, A., Lohr, U., 1999. Airborne laser scanning - an introduction and overview. ISPRS J. Photogramm. 54, 68-82.

Wesche, K., Partzsch, M., Krebes, S., Hensen, I., 2005. Gradients in dry grassland and heath vegetation on rock outcrops in Eastern Germany - an analysis of a large phytosociological data set. Folia Geobot. 40, 341-356.

Zalatnai, M., Körmöczi, L., 2004. Fine-scale pattern of the boundary zones in alkaline grassland communities. Com. Ecol. 5, 2246-2335.

Zalatnai, M., Körmöczi, L., Tóth, T., 2007. Community boundaries and edaphic factors in saline-sodic grassland communities an elevation gradient. Tiscia 36, 7-15.

Zar, J.H., 1999. Biostatistical Analysis. Prentice Hall International, London.

Zedler, J.B., Callaway, J.C., Desmond, J.S., Vivian-Smith, G., Williams, G.D., Sullivan, G., Brewster, A.E., Bradshaw, B.K., 1999. Californian salt-marsh vegetation: an improved model of spatial pattern. Ecosystems 2, 19-35. 